\title{
QUALITY ASSURANCE IN THE CONTEXT OF EUROPEAN INTEGRATION
}

\section{LA GARANTIA DE CALIDAD EN EL CONTEXTO DE LA INTEGRACIÓN EUROPEA}

\author{
Nadezhda F. Efremova \\ Besarion Ch. Meskhi \\ Svetlana V. Shvedova
}

\begin{abstract}
The article provides information on problems of the education internationalization, the basic principles of integration of higher education and programmes aimed at ensuring the quality of training in European and Eurasian educational spaces. Particular attention is paid to existing approaches to guarantee the quality of higher education and the formation of quality assessment systems at the international, national and regional levels to create the conditions for relevant quality management of education. The construction of an effective system for ensuring and assessing the quality of education in many countries of the world, including Russia, is one of the priorities of the national educational policy. This article is aimed at expanding knowledge about the integration processes in the field of education by using new teaching technologies, research and debates on topics related to the history, politics, economics and legislation of the European Union, as well as EU relations with other regions of the world.
\end{abstract}

Key words: Bologna Process, European integration, higher education, internationalization, quality assurance

\section{RESUMEN}

El articulo proporciona información sobre problemas de la internacionalización, los principios básicos de la integración de la educación superior y programas de estudios destinados al mejoramiento de la calidad de la educación superior en espacios europeo y euroasiático. La atención especial se da a los enfoques existentes de la garantía de la calidad de la educación superior y la formación de los sistemas de calidad a nivel regional, nacional e internacional para crear las condiciones para la gestión de la calidad educativa. El artículo tiene por objetivo aportar el conocimiento sobre los procesos de la integración en el campo de la educación por el medio de la tecnología, la investigación y los debates sobre los temas relacionadas con historia, política, economía y legislación de la Unión Europea, así como las relaciones de UE con otras regiones del mundo.

Palabras clave: Proceso de Boloña, integración europea, educación superior, internacionalización, garantía de calidad. 
QUALITY ASSURANCE IN THE CONTEXT OF EUROPEAN INTEGRATION

Nadezhda F. Efremova; Besarion Ch. Meskhi y Svetlana V. Shvedova

JOURNAL OF SUPRANATIONAL POLICIES OF EDUCATION, 2019, nº10, pp.40-56

DOI: https://doi.org/10.15366/jospoe2019.10.003

JOURNAL OF SUPRANATIONAL POLICIES OF EDUCATION, ISSN 2340-6720 


\section{ORIGINS, DYNAMICS AND LOGIC OF BOLOGNA PROCESS}

Today, the world is at the cusp of innovations wave, accelerating "inflation of qualifications", when the current knowledge and competencies may turn out to be unclaimed tomorrow and become a limitation for the further socio-economic development of not only the individuals, but also the whole regions. These changes will force a radical revision of the world education system. Largescale innovations in education are extremely rare; over the last millennium, four global changes can be distinguished (Abdulkerimov, Pavlyuchenko, Esetova, 2012, p. 358 - 361):

- X - XII centuries: emerging of universities in Europe focused on translation of knowledge (Bologna, Paris, etc.);

- The 1640th year, Jan Amos Comenius introduced a class-lesson system, which became the pedagogical norm for mass, first of all, school education;

- XIX century: emerging of research type universities for the generation of scientific knowledge and the training of researchers according to the model of V. von Humboldt;

- Between XIX and XX centuries: there is a development of design and "active methods" of teaching as a pragmatic education and experimental method (the American philosopher John Dewey).

At the end of the twentieth century, the education system, which developed over thousands of years, accumulated the best of world educational practice and absorbed the achievements of the best minds, ceased to satisfy the needs of society. The level of socio-economic development has led to a number of challenges to national educational systems, the solution of which became possible only with international integration in education. At two conferences of rectors of European universities (in 1959 and 1964) there were attempts to find out what training graduates of European universities should be like. The concept of a single European space for higher education has been ripening since the signing of the Maastricht Agreements on the establishment of the European Union, and the "European dimension" has since become the common goal, later enshrined in the Bologna Declaration. Thus, the conditions for the fifth global innovation in education have ripened, it is expressed in the form of the Bologna process, covering not only European countries. This condition in the education of F.G. Altbach, L. Reisberg and L.E. Rumble in his report at the UNESCO World Conference on Higher Education called the beginning of the "academic revolution" (Anichkin, 2015, p.p. 47-52).

In 1995, in pursuance of the decisions of the General Conference, UNESCO developed a Programme document entitled "The reform and development of higher education", which synthesizes theses trends and objectives of the development of higher education at the turn of the century. In the introduction to the Document, among the main tasks of higher education in a rapidly changing world, three main areas are identified: compliance with the requirements of the present; internationalization; quality as "a multilateral concept encompassing all the basic functions and activities of higher education."

The forerunner of the Bologna process was the Lisbon Convention on the Recognition of Qualifications Related to Higher Education in the European Region (April 1997), which proposed a common approach to the formulation of qualifications for universities in different countries. The beginning of the Bologna process was the Sorbonne Agreement (May 1998), which analyzes the structure of higher education in Europe, signed by the education ministers of Germany, Britain, Italy and France, who gathered to celebrate the 800th anniversary of the Sorbonne University. In June 1999, the Ministers of Education of 29 European countries in Bologna (Italy) signed the Bologna Declaration, which declared the Concept for the formation of a single European Higher 
Education Area (EHEA) and laid the foundation for the so-called Bologna Process (Altbach, Raysberg, Rumbley, 2010, p.p. 58-94).

The logic of the Bologna Declaration is defined by the following points: importance of education and academic cooperation; the new mission of the university as a center of culture, knowledge, research; European universities play a major role in building the European Higher Education Area; increasing international competitiveness of the European higher education system.

In order to develop common approaches to the quality of higher education, the education ministers of several European countries have developed the main objectives and provisions of the Bologna Declaration, formulating 10 key indicators. These include: the introduction of a two-level system (undergraduate and graduate programmes); accessibility of all levels of higher education; implementation of a unified approach to the formation of a national qualifications framework; development of an external system for ensuring the quality of education; student participation in ensuring the quality of education; international participation in ensuring the quality of education; introduction of a European diploma supplement; implementation of the principles of the Lisbon Convention on the recognition of qualifications; introduction of a European credit system and recognition of periods of prior studies.

To the previously formulated tasks are added: introduction of graduate school in the general system of higher education (as a third level); giving the "European dimension" to higher education (its focus on pan-European values); increasing the attractiveness and competitiveness of European education; realization of the social role of higher education, its accessibility; development of the system of continuing education, as well as implementation of the strategy "lifelong learning".

One of the main tasks of the Bologna process is to improve the description of qualifications and qualification structures throughout the European Higher Education Area in terms of learning outcomes that will allow us to express what should be achieved by students and how they can confirm this achievement (Altbach, Raysberg, Rumbley, 2010, p.p. 58-94).

Then, the Conference of Ministers of Education of the countries participating in the Bologna process began to be regularly held. They are the highest body and make decisive decisions in the areas of development of the Bologna process. It should be noted that joining the Bologna process does not impose any obligations from the legal point of view on the member countries. This is a process of voluntary cooperation, which involves modernization of national higher education systems in accordance with the jointly defined areas of development of the Bologna process. The system for managing the meetings of Ministers is presented in Table 1 (Anikina, Ivankina, Sorokina, 2016).

Table 1.

Bologna Process Management Structure.

\begin{tabular}{|c|c|c|}
\hline Level 1 & \multicolumn{2}{|c|}{$\begin{array}{l}\text { Conferences of Ministers of Education } \\
\text { countries participating in the Bologna process }\end{array}$} \\
\hline \multirow[t]{2}{*}{ Level 2} & \multicolumn{2}{|c|}{$\begin{array}{l}\text { Bologna Process Monitoring Group } \\
\text { (Bologna Follow-up Group): the group includes all the member countries of the } \\
\text { BP, as well as the European Commission, the supporting structure is the } \\
\text { Secretariat (Bologna Secretariat) }\end{array}$} \\
\hline & $\begin{array}{l}\text { Chairman: } \\
\text { EU country presidency }\end{array}$ & $\begin{array}{l}\text { Vice Chair: the country hosting next } \\
\text { meeting of Ministers of Education }\end{array}$ \\
\hline
\end{tabular}




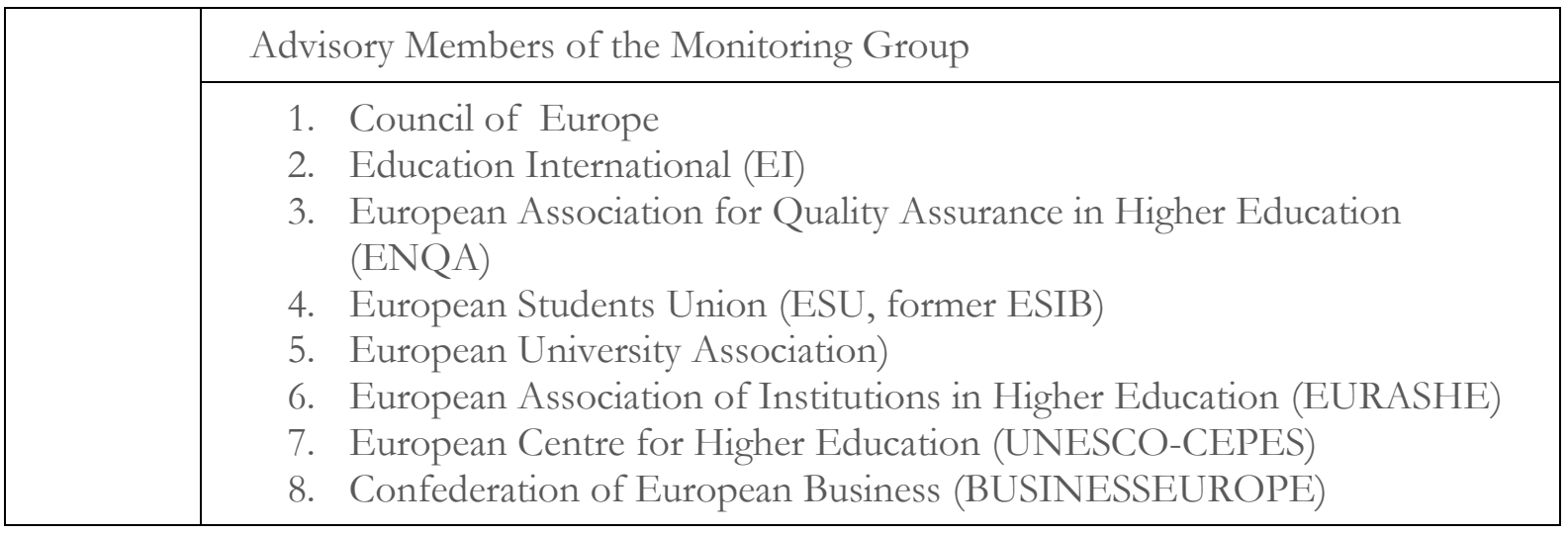

Source: Crosier D, Parveva T. (2013)

The main stages of the Bologna process development. The Bologna Follow-Up Group (BFUG) was formed in Prague (May 2001) from representatives of 33 participating countries and the European Commission. The stages of development of the Bologna process were adopted, an action plan was prepared to ensure the mobility of students and academic staff, the forms of cooperation in the field of quality assurance and the European Higher Education Area in the world were determined; the directions of promoting lifelong learning, involving students in the process of creating the European Higher Education Area (EHEA) are formulated, diploma comparability systems using the ECTS (European Transfer Credit System) are proposed.

Berlin (September 2003, Russia joined the Bologna process): Ministers of education of 40 countries focused on the need to create a common model of higher education in Europe, the question was raised about the development of interaction between the EHEA and the European Research Area. The task is to develop standards for ensuring the quality of higher education at the university, national and European levels; adopted systems of understandable and comparable qualifications of higher education and diploma supplements. Following the conference, a Communiquéwas adopted on the implementation of the Bologna process, aimed at ensuring that national higher education systems provide development of national qualification structures and degrees (bachelor and master) which are to be described in terms of learning outcomes. The task is to develop an acceptable set of agreed standards, procedures, quality assessment methods, as well as an adequate system of external examination to ensure quality or a system of accreditation agencies (bodies).

The Berlin Communiqué described adoption of a system of adequately formulated and comparable degrees and general terminology for describing qualifications in order to make them more understandable for other universities, employers and those involved in the assessment of qualifications, which made the process of recognizing periods of study in other universities possible and relevant. In many respects, it is at the second cycle level that universities show innovation and creativity, therefore the emergence of new types of master's programmes should be considered as the basis for the development of the strengths of higher education in Europe (Baidenko, 2004, p.176). For this, the European Credit Accumulation and Transfer System (ECTS) is proposed, based on the principle that 60 credits evaluate the workload of a full-time student for one academic year. Using the learning outcomes as a general method for describing programmes and modules can help establish common standards and common quality assurance methods for higher education institutions, and students can understand what is expected at the end of a given programme or module.

According to the final Communiqué of the Berlin Conference, postgraduate training should become the third stage of higher education, as a result of which the following higher education 
scheme will be implemented in European countries: bachelor - master -Doctor of Philosophy $(\mathrm{PhD})$. The decision to include educational programmes at the $\mathrm{PhD}$ level as the third stage of higher education is due to the recognition of research component importance for the full functioning of the higher education.

Bergen (May 2005): participants from 45 countries (Armenia, Azerbaijan, Georgia, Moldova, Ukraine joined the Bologna process) approved the European Standards and Guidelines for Quality Assurance of HE (ESG) as examples of successful / effective practice. A peer review model has been adopted within quality assurance agencies; It is recommended to develop and adopt national procedures for the recognition of foreign documents on education, degrees and periods of study; a decision was made to approve higher education quality assurance standards developed under the leadership of the European Association for Quality Assurance in Higher Education (ENQA) to coordinate independent training quality control systems within EHEA (Abdraimov, 2009). Formation of the European Quality Assurance Register for Higher Education with an information resource and a list of quality assurance agencies in Europe that meet the requirements of the ESG (confirmation by external parties) - www.eqar.eu.

European quality assessment standards include: quality assessment policies and procedures; monitoring and periodic checks of study programmes and qualifications; assessment of student knowledge; quality of teaching staff; student learning and support resources; information systems; public awareness.

A significant factor in ensuring the quality of education is the existence of an independent assessment system for the quality of higher education, based on a system of independent organizations (external expertise) while expanding the autonomy of universities and transferring to them the primary responsibility for the quality of education. This led to the creation of university systems for assessing the quality of education. The Quality Management Systemwas introduced in Russian universities (Fig. 1).

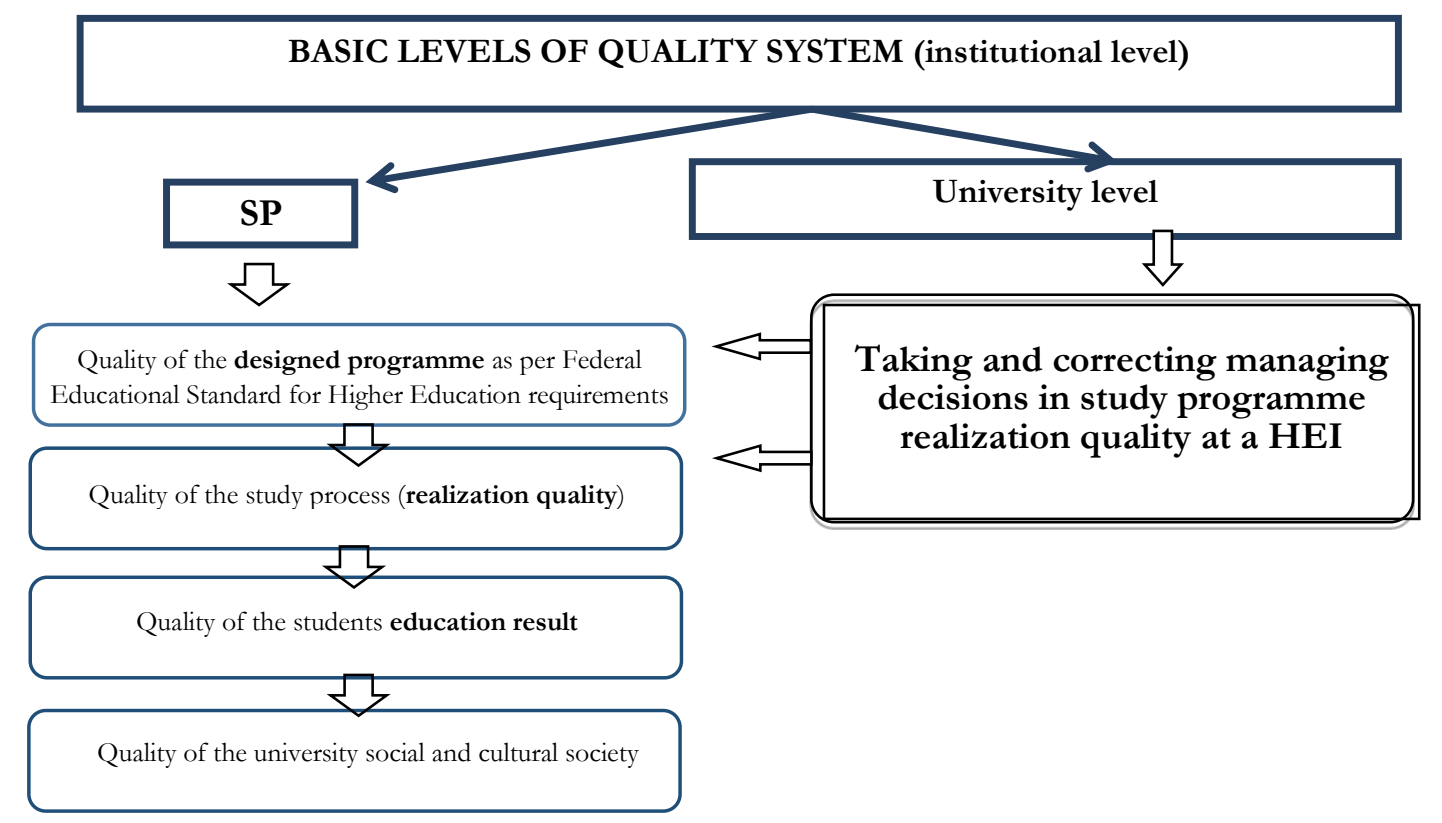

Figure 1. Intra-university quality systems of higher education.

Source: Efremova N.F. (2015) 
An understanding of the definition of "quality of education" in Europe is given according to the model of the "European Network for Quality Assurance in Higher Education". These include quality of teaching staff; research and innovation activities of the university; state of material and technical base of the educational institution; quality of study programmes; student knowledge quality; quality of student learning outcomes; the demand for graduates in the labor market; graduate achievements. The main guidelines for the EHEA countries at the present stage: learning outcomes, use of tools such as the European Standards and Guidelines (ESG), ECTS and the European Diploma Supplement, introduction of limited terms for the recognition of degrees and qualifications (no more than 4 months), application recommendations and technologies presented in the European Area of Recognition Manual (EARM). European recommendations for external examination included: the procedures of the university system of quality assurance for external examination; coordination and approval of external examination procedures; decision criteria; compliance of the procedures with the goals and objectives of the examination; report publication; identification of subsequent procedures; the frequency of the external examination procedure; research function to identify positive experiences and problems.

"Standards and Guidelines" for Quality Assurance in the European Higher Education Area contains a standard model for quality assurance, which consists of 7 main elements and recommendations for their implementation:

- development and implementation of a university strategy for continuous quality improvement; Moreover, the strategy, programme and procedures should have a formal status and be publicly available;

- presence of formal mechanisms for the approval, monitoring and regular evaluation of programmes;

- assessment of students' knowledge in accordance with consistently applied published criteria, regulations and procedures;

- availability of a quality assurance system for the teaching staff;

- availability of information resources and student support systems adequate to the learning objectives;

- availability of information systems that provide effective management of study programmes and other university activities;

- regular updating and publication of objective and reliable information about university programmes (Higher school: problems and prospects: 12th Intern. scientific method. conf., 2015, p. 246).

London (May 2007): 46 countries (Montenegro adopted) announced the creation of the European Quality Assurance Register for Higher Education (EQAR) in accordance with ENQA standards and recommendations. The EHEA in a global environment strategy has been adopted, which defines mechanisms to promote its attractiveness and increase competitiveness, strengthen cooperation, and enhance dialogue on recognition issues; graduate school is defined as the third stage of higher education; and also recommendations were made to create conditions for ensuring the employment of university graduates after each training cycle.

In 2008, the European Qualifications Framework (EQF) was approved, operating on the territory of the European Union, which allows comparing qualifications and educational degrees, and also creates the basis for mutual recognition of higher education programmes of different countries. In many European countries, the National Qualifications Framework (NQF) is being formed or has already been formed (Bidenko, 2009, p. 536). In Russia, the NQF has not yet been fully formed. But as regards the recognition of degrees and qualifications, the National Report to the Ministerial 
Conference in Yerevan (2015) notes the active position of Russia in implementing the goals and provisions of the Lisbon Convention on the recognition of qualifications related to higher education in the European Region (Lisbon, 1997) [Yerevan Communiqué, 2015].

Leuven / Louvain-la-Neuve (April 2009) - a decision was made to increase the number of students participating in academic mobility up to $20 \%$ by 2020 and the need to integrate science and education at all levels as a development of the "Europe of knowledge" was declared. It is noted that higher education at all levels should be based on the current state of research and development, thereby contributing to innovation and the development of society. The most important priority is the increase in state investment in higher education and ensuring equal access for all citizens to higher education, as well as the inclusion of production practices and on-the-job training in educational programmes. The main emphasis is madeon implementation of measures to develop various forms of support during the training period, the use of flexible educational paths and alternative ways of access to different levels of education, including recognition of previously acquired education, including non-formal. It is possible to get a Bachelor's degree in one field and choose a Master's degree in another one. This approach promotes mobility of teaching staff and students, export of educational services, mutual enrichment of national educational systems, as well as formation of a competitive market for specialists with higher education.

Budapest-Vienna, March 2010: with the participation of 47 countries (adopted by Kazakhstan), the results of the implementation of the tasks set earlier were summed up. The Bologna process creates conditions for standardization and ensuring the quality of education; internationalization and the consolidation of economic, political and cultural ties; flexible change of training profiles in a situation of rapidly changing demand for professions. The establishment of the EHEA is announced, the priorities for the development of the EHEA until 2020 are specified.

Leuven / Louvain-la-Neuve, Romania, Bucharest April 26-27, 2012: the VIII Conference of Ministers of Education of the countries participating in the Bologna Process and the III Bologna Political Forum "Mobility to improve the quality of education. Mobility Strategy 2020 for the European Higher Education Area". The political guidelines in the development of higher education for the subsequent period are determined; the Communiqué "Maximizing our potential: consolidating the EHEA", "Strategy for the development of mobility in the EHEA for the period until 2020", Joint statement "Beyond the Bologna Process: the creation and interaction of the national, regional and global space of higher education" were adopted. The Bologna process leads to greater compatibility and comparability of higher education systems and facilitates the involvement of students and scientists from other continents. To date, in most Western European countries, multi-level training systems are functioning, the introduction of a system of comparable loans is being completed, and the problem of mutual recognition of qualifications has actually been solved.

By that date, all EHEA countries have switched to a three-tier system of higher education (undergraduate, graduate, and graduate programmes). The main tools of the Bologna process are the European Credit Transfer and Accumulation System (hereinafter - ECTS), the European Diploma Supplement, mechanisms for recognizing periods of study in other universities, and national qualifications frameworks.

Armenia-Yerevan, May 2015: 48 participating countries (Belarus joined) approved a common three-tier system of higher education, a comparable system of accumulation and transfer of loans (ECTS), common quality standards that ensure cooperation and mobility of students and staff, the principles of joint programmes and mutually intelligible degrees as the basis of the EHEA (Fig. 2). It is planned by 2020 to include in all countries participating in the EHEA, where the automatic recognition of qualifications will become a reality. Universities are recommended to use any agency 
registered in the EQAR as an external assessment to ensure external accreditation of programmes and to ensure the quality of education.

The 2015 Yerevan Communiqué focused on the recognition of education documents (Efremova, 2017, p.p..227-244) (Fig.2). In this regard, the priorities announced until 2020 are: the transition to the automatic recognition of qualifications within the framework of the Bologna system; building, through higher education, an inclusive society based on democratic values and civil rights; development of educational programmes necessary for the European labor market. The Bologna Policy Forum forum adopted the revised Standards and Recommendations to ensure the quality of higher education in the EHEA, the implementation of which will accelerate the recognition of diplomas and qualifications at the international level. At the transnational level, internationalization is manifested in the development of general principles for the development of higher education to align the quality of graduate training and strengthen international cooperation.

The EHEA Ministerial Conference was held in Paris on May 24-25, 2018. It was opened to registered European Higher Education Area (EHEA) delegations and included a Bologna Policy Forum that was an opportunity to pursue a dialogue between EHEA and non-EHEA countries. The Paris Conference was an opportunity to reinforce the cooperation between countries for a better future of higher education. The Communiqué stresses the necessity to improve the implementation of fundamental values, especially democracy, since the standards of higher education convey notions of peace and freedom.

Table 2. The Yerevan Ministerial Conference in 2015 - EHEA countries (2019).

\begin{tabular}{|l|l|l|}
\hline - Austria & - Iceland & - Russia \\
- Azerbaijan & - Spain & - Romania \\
- Albania & - Italy & - Serbia and Montenegro \\
- Andorra & - Syprus & - Slovakia \\
- Armenia & - Latviania & - Turkey \\
- Belarus & - Lithuania & - Ukraine \\
- Belgium & - Liechtenstein & - Finland \\
- Bulgaria & - Luxembourg & - France \\
- Bosnia and Herzegovina & - Macedonia & - Croatia \\
- Vatican & - Malta & - Czech Republic \\
- Great Britain & - Moldova & - Montenegro \\
- Hungary & - Netherlands & - Switzerland \\
- Germany & - Norway & - Estonia \\
- Greece & - Poland & $\mathbf{4 8}$ countries in total \\
- Georgia & - Portugal & \\
\hline
\end{tabular}

Source:http://www.ehea.info/media.ehea.info/file/2018_Paris/70/8/EHEAParis2018-List ofattendees_958708.pdf

The meeting of the Bologna Follow-Up Group which was held in Helsinki, Finland, in 2019 addressed the implementation of the programme period 2018-2020, outlined a new strategic programme for 2020-2030 and prepared a ministerial declaration for 2020. The main topics were: qualifications frameworks, recognition, and quality assurance. As concerns the coherence between the different structural reform areas and tools - qualifications frameworks, recognition, and quality 
assurance - Brian Maguire from Quality and Qualifications Ireland shared his experience and ideas. In particular, he stressed the following items:

- The crucial link between quality assurance and Qualifications frameworks both in terms of qualifications themselves, of the recognition process and of higher education institutions. In terms of recognition, the subsidiary text to the Lisbon Recognition Convention on "the use of QF in recognition practices" is a central element of the work of the ENIC and NARIC centers and Networks, including through a peer group activity on the quality of the recognition process.

- The question of the coherence of the three pillars of structural reforms is important not only at European but also at national level. Updated Standards and recommendations for quality assurance in the European Higher Education Area (2015 version) were adopted. The main goal is to build a common understanding of the quality of teaching and learning in all countries and for all interested parties. Participation in quality assurance processes, especially external ones, provides an opportunity for European higher education systems to demonstrate quality and increase transparency, promoting the formation of mutual trust, improving recognition of qualifications, programmes and other aspects related to the implementation of educational activities.

The objectives are the following:

- to provide support for universities in the development of innovative educational programmes, including using modern information technologies, targeting labor market programmes;

- to strengthen the dialogue with employers, the formation of programmes with a balanced ratio of theoretical and practical parts;

- to develop inclusive education programmes in the context of the increasing diversification of European societies, inclusive education is based on an ideology that eliminates any discrimination and ensures equal treatment of all people, including those with special educational needs;

- toimplement of previously agreed structural reforms with a focus on creating a unified system of educational degrees and credits, harmonizing the quality standards of higher education, and cooperation with the goal of increasing academic mobility.

It is expected that the formation of new technologies in world industry can be determined by 2025 , which will require fundamentally new professional competencies from employees and ordinary consumers ("users"), which today is not always possible to predict. The world lives in conditions of accelerating "inflation of qualifications", when the current competencies may turn out to be unclaimed tomorrow and even more - become a limitation for further socio-economic development (Abdulkerimov, Pavlyuchenko, Esetova, 2012, p. 361).

Today it is important to understand that the main task is for all participants in the Bologna process to understand the need for the full implementation of the basic goals of creating the EHEA. However, as practice shows, this cannot be achieved for many reasons that impede the equal involvement of countries in this project. These include insufficient diversification of forms of academic mobility and the gap between economically developed and undeveloped countries, a partial or some revisionist approach to the implementation of the basic values of the Bologna process, the cognitive division of the European space into a "center" (Great Britain, Germany) and "periphery" (Baltic countries). In many countries, mobility of students and teachers is associated with a "brain drain" (Efremova, 2015, p.416.).

To eliminate the obstacles to the mobility of teachers in the Russian Federation, it is proposed: to 
develop standard models of regulatory documents in accordance with the authority of the PSA; improve migration legislation; provide for a special procedure for filling the positions of scientific and pedagogical workers of universities (election by competition) for foreign teachers, etc.

Problems and prospects for the development of education, which educational systems face in different countries of the world, are relevant in Russia and determine the direction of modern educational policy. Of particular interest is the development of student mobility in the post-Soviet space by restoring lost ties with the countries of the Russian-speaking space. Institutional and grant support for the mobility of teachers and students is needed, and the main emphasis in this work should be placed on institutional flexibility, stimulating the career prospects of exchange participants both when traveling to partner countries in order to gain experience, and when returning to their institutions specialists who have received experience abroad.

\section{INTERNATIONALIZATION OF HIGHER EDUCATION}

In recent decades, the development of education in many countries involves the widespread use of information and communication technologies, recognition as a priority to ensure the conditions for the development of a knowledge economy, and the introduction of innovative pedagogical technologies. This necessitates active and effective cross-country cooperation in order to enrich and exchange experience in the field of education. The process at the national, sectoral and institutional levels, in which the goals, functions and mechanism for the provision of educational services becomes international, is the internationalization of higher education. Internationalization is seen as a tool to enhance the influence of the university at home and abroad through the development of strategic partnerships, the expansion of the academic community, the mobilization of internal intellectual resources to expand the competencies of graduates in accordance with the challenges of the global labor market and the requirements of employers. Ultimately, internationalization is one of the ways to achieve the university's international status in the global educational space and, as a result, ensures a high level of education quality.

The fundamental ideas of the internationalization of the educational services market are (Smirnova, 2016): strengthening the international competitiveness of higher education and research; creation of conditions for entering the international educational market; positioning the national system of higher education as an active participant in the international space of education.

Internationalization is a systemic and multi-format process that allows achieving both academic and economic goals. This is the diversification and growth of financial revenues through the expansion of the export of educational services; ensuring the quality of educational programs and expanding the "window" of academic mobility; strengthening networking, including for the efficient use of available resources; improving the quality of research by participating in the international process of sharing knowledge, technologies, etc.

Goals of internationalization.

The goals are divided into academic and economic ones:

- The academic goals are aimed at increasing education and researches quality through students and lecturers participation in international academic mobility and educational programmes modernization taking into account the European dimension.

- The economic goals provide financial stability and sustainable development due to additional funding sources involvement and intellectual product income generation.

The internationalization of education includes such forms of mutual cooperation as the mobility of students and faculty for educational purposes; exchange of study programmes and institutional mobility; formation of international quality standards for educational programs; integration into of 
the international dimension curricula; institutional partnership; creation of strategic educational alliances. The undoubted advantages of internationalization include the increased accessibility of higher education, the universalization of knowledge, the innovativeness of educational technologies, as well as the expansion and strengthening of international cooperation, the transfer of knowledge and technologies, and the expansion of multicultural competencies of students and teachers (Abdraimov, 2009).

Forms of internationalization include participation in international educational projects, the purpose of which is to create international educational programmes and improve the quality of the educational process in universities.

One such research program is the "Jean Monnet Chair" project, created by the European Commission in 1989 in memory of the contribution of Jean Monnet (1888-1979), an outstanding French politician, economist, financier and ideologist of the European Union to the development of European integration.

The Jean Monnet programme provides raising the knowledge level in the world and conducting European research. Today, this program is part of the Erasmus+ programme of the European Commission.

Participation in the Jean Monnet programme provides ample opportunity to establish and develop academic partnerships. The aim of this program is to ensure the high quality of teaching, research, analysis and dialogue in the field of European integration disciplines in higher education institutions of the EU countries and beyond. The main objective of the program is to bring the European dimension into national higher education systems.

This programme is implemented in three main areas:

- “teaching and research": modules Jean Monnet (Jean Monnet Module), departments Jean Monnet (Jean Monnet Chair), centers of best practice Jean Monnet (Jean Monnet Centers of Excellence), monitoring and leading research in various disciplines and educational levels, in including such as teacher training, with the systematic publication of the results of research activities;

- "dialogue between politicians and the academic environment", implemented through Jean Monnet networks with the aim of collecting and disseminating information on the teaching methodology, the results of European and joint research, involves cooperation between various educational organizations and other bodies in Europe and around the world;

- "supporting the activities of educational organizations and associations" (Jean Monnet Association), engaged in research with the EU in the field of European integration issues for the subsequent consultation of local, regional, national and European politicians, disseminating research results, increasing civic engagement.

The rapid development of internationalization, international academic mobility and transnational institutions make it possible to consider higher education as a phenomenon that determines the need for recognition of diplomas and qualifications. Of particular importance in these processes is ensuring the quality of education, updated by the adoption of the communique of the Tenth Conference of Ministers of Education and the Fourth Bologna Political Forum in Paris in 2018. The Paris Communiqué stated the following priorities: development of study programmes related to the development of the European labor market; transition to automatic recognition of qualifications within the Bologna system; building an inclusive society based on democratic values and civil rights; effective implementation of coordinated structural reforms focused on creating a unified system of educational degrees and loans; ensuring uniform approaches to the quality standards of higher education; cooperation with the goal of increasing educational mobility [Higher school: problems and prospects: 12th Intern. scientific method. conf., 2015]. 
In particular, by 2020 the goal is to ensure guarantees of mutual trust in higher education systems of the countries participating in the Bologna process in order to achieve greater compatibility and comparability of national higher education systems in order to improve its quality and ensure student mobility.

\section{EURASIAN EDUCATION INTEGRATION DIRECTION}

It should be noted that there is a number of factors that negatively affect the pace of formation of the general educational space, including a number of objective circumstances: the difference in national education systems, the demographic situation in regional states, and fundamentally different economic conditions that ensure the quality of pedagogical and educational resources, and, accordingly, the level of development of competencies of graduates, the lack of regional infrastructure. On the whole, the modern stage in the development of education in the world is characterized by a special intensity of transformations that equally affect organizational and managerial structures, goals and contents, teaching methods and technologies, sources and mechanisms of financing, as well as the conditions and forms of international educational cooperation (Lobanov, 2015, p.582). Solving the problems of creating a single educational space requires a coordinated collaboration, and the formation of a common educational space as a basis for integration is relevant not only for the signatory countries of the Bologna Declaration, but also for partner countries.

In the educational sphere, Russia pursues a "three vectors" policy: entering the Bologna process, developing integration processes in the post-Soviet space through the implementation of bilateral and multilateral projects, educational integration within the framework of the SCO and BRICS countries.

The European vector for the development of integration relations is a prestigious direction of entering the world educational space of higher education and scientific research.

However, the real orientation and prospects of educational interaction is due to the demand for the package of exported educational services. Statistics show that the number of students from Europe has a steady downward trend, while the number of students from Asia is gradually increasing. At the same time, the SCO member states demonstrate the greatest interest in the Russian educational system, and the Russian-Chinese vector of humanitarian cooperation is currently developing most dynamically.

A new type of civilizational community unites people not on the basis of their national origin or religion, but in accordance with the community of cultural preferences and a single cultural code, based on their free choice of their cultural and civilizational identity. Intercultural dialogue remains relevant as the basic value of the modern global humanitarian space. In this, the decisive role is played by education, its international character, the consistency of criteria for the quality of training of specialists and methods for its assessment.

A natural consequence of the internationalization and globalization of education is its integration, which occurs most intensively between countries that have common historical and civilizational roots, comparable levels of socio-economic development and, as a consequence, similar problems. The diversity of peoples, cultures, languages and religions makes Eurasia one of the most interesting regions of the world for integration processes in the field of education. The Eurasian model of integration is becoming increasingly attractive, being the most relevant and promising process precisely within the framework of the community of post-Soviet states. These educational systems are characterized by: development in one state in the past; Russian language as an instrument of international communication; identical problems of transition to the bachelor- 
master-doctor system; the need to harmonize the qualifications system, the intensive development of international and inter-university cooperation, etc.

One of the characteristic features inherent in post-Soviet states is the high speed of reform and modernization of education systems. In the integration processes in the Eurasian space, Russia plays the role of a key participant, accumulating experience in political, economic, scientific, educational and sociocultural interaction, especially in regional and integration processes taking place in the Commonwealth of Independent States (CIS). Russia's actions on Eurasian integration have a fundamental, well-thought out and historically readable basis. The ideas of educational integration in the Eurasian direction are being developed according to the principles of the "Eurasian Bologna process" using the experience of the SCO Network University (SCO) (Oleinikova, 2010, p.p. 7-10, Rychen, Salganik, 2003, p.224). The Eurasian space of higher education is developing in a separate organizational format that promotes the convergence of standards in education and science and enhances regional academic mobility. The concept of the "Eurasian Higher Education Area" is based on the principles of "learning from each other", "communicating with each other", "exchanging with each other" (Oleinikova 2012, p.85).

In the Eurasian space, two directions are most noticeably developing: exchanges with participation of Russia and China, as well as relations in the field of education and science between Russia and the countries of Central Asia, which still have a post-Soviet transformational model that facilitates integration processes.

A great achievement of the Eurasian educational space is the project of the network university of the Shanghai Cooperation Organization (SCO), in which 76 higher educational institutions from 6 countries, including 23 Russian, participate. Moscow State University M.V. Lomonosov has branches in Kazakhstan, Tajikistan and Uzbekistan, work is underway to create a Joint University of Moscow State University and the Beijing Polytechnic Institute in the Chinese city of Shenzhen. The idea of educational integration in the Eurasian direction is being developed, in particular, by the Russian Council on International Affairs in the framework of the project "Shanghai Cooperation Organization: Model 2014-2015" (Tereshkovich, 2016, p.149). Numerous bilateral agreements have been signed on cooperation between scientific and educational institutions of Russia and the SCO countries. The SCO countries today include India, Pakistan, Tajikistan and Uzbekistan, Kyrgyzstan, Kazakhstan, China and the Russian Federation. A number of countries declare joining the organization: Mongolia, Afghanistan, Iran, Belarus, etc.

The convergence of educational standards and the improvement of the system of mutual recognition of scientific and educational results within the framework of Eurasian educational integration will help stimulate academic mobility between the countries of the Shanghai Cooperation Organization (SCO), as well as create an expert scientific and cross-cultural base for the successful socio-economic development of the entire Eurasian region. One indicator of the development of scientific exchanges is the statistics of joint international publications. Thus, the share of publications in collaboration with Russian researchers in the total number of publications in the country is $23.44 \%$ for Kyrgyzstan, 23.18 for Kazakhstan, 15.45\% for Uzbekistan and 14.81\% for Tajikistan.

In order to consolidate the professional community, expand and promote the expert potential of Russia and the countries of the Commonwealth of Independent States (CIS), as well as disseminate existing experience in assessing the quality of education and new technologies in the field of control and evaluation activities in Eurasia in 2012, the Eurasian Association for Educational Assessment was created by leading Russian scientists educational quality assessment (EAOKO) [Neumann, Khlebnikov, 2019, p.168]. One of the key objectives of EAOKO is to promote the development of methodology and expert research in the field of assessment and analysis of the quality of 
education, development of assessment tools and their specific application. To achieve these goals, EAOKO activities are aimed at developing, supporting and implementing projects in the field of education quality assessment, organizing thematic seminars, conferences and trainings in the field of quality assessment and education management, and developing international cooperation in this area. EAOKO provides interaction between the expert community of the countries of the Eurasian region and other international organizations, promotes regional analysis of international monitoring and assesses the quality of education, in addition, by representing the Eurasian expert community, it promotes the latest developments in the field of assessing the quality of education abroad, in order to ensure for Eurasian experts access to international resources and events, international experience in assessing the quality of education.

The main areas of work of EAOKO are:

- improving the relationships between organizations involved in the academic assessment of knowledge through the exchange of experience through conferences and publications; ensuring structural work, within the framework of which joint research, training and projects are carried out;

- cooperation in the search for assessment technologies that are most suitable for solving educational problems;

- participation in measures to improve assessment technologies and their implementation in the educational structures of the participating countries.

The Association holds annual international conferences in various countries, including the Eurasian region: 2012, Moscow, Russian Federation: "Integration, partnership, innovation in the field of education quality assessment"; 2012 Astana, Republic of Kazakhstan: "Modeling the evaluation procedure with the goal of positive impact on individuals and educational institutions"; 2013 Tel Aviv (State of Israel): “Assessment in Education: Assessment Technology in Education"; 2013 Minsk, Republic of Belarus: "Monitoring of school education - prospects for intercountry cooperation"; 2014 Astana, Republic of Kazakhstan: "Features and directions of development of national systems for assessing the quality of education"; 2014 Republic of Singapore: "Evaluation of 21st Century Innovation"; 2015 Kazan (Republic of Tatarstan): "An independent assessment of the quality of education: modern challenges and best practices"; 2015 Kansas (United States of America): "Three main aspects of testing: validity, validity, validity"; 2016 Cape Town (South Africa): "Assessing the achievement of educational program standards - continuous dialogue"; 2016, Issyk-Kul (Kyrgyzstan): "Management of the quality of education based on assessment"; 2017 St. Petersburg (Russia) "Monitoring, ratings, rankings as tools for managing the quality of education".

In order to integrate into the general educational space, regional conferences on higher education are held, contacts are established with international and regional organizations, and educational and research programmes are developed and implemented (Barber, Donnelly, Rizvi, 2013, p. 72).

While promoting and developing the concept of the Eurasian space of higher education, it should nevertheless be remembered that the ultimate goal of Eurasian educational integration is to improve the quality of higher education in Russia and the countries of the region as a whole. Orientation towards Eurasia is not considered as an exclusive alternative to Russia's participation in integration educational processes in other regions of the world. Therefore, international cooperation is also carried out in the framework of bilateral agreements and memoranda. In 2007, an agreement on cooperation in the field of education quality assessment was signed between the NTC and the State Student Admission Commission of the Republic of Azerbaijan, the National Accreditation Agency for Education of the Russian Federation and the National Testing Center (NTC). In 2013, a memorandum of cooperation was signed between the National Testing Center 
and the TOMER Center (Turkish Republic, Ankara, Gazi University, Turkish Language Learning, Research and Practice Center). In 2014, a memorandum of cooperation was signed between the National Research University Higher School of Economics and the NTC. Within the framework of the memorandum, training seminars and trainings are held for the specialists of the NTC on the interpretation and presentation of the results of the assessment of educational achievements for various groups of users of the theory and practice of test development in psychology and education. Contacts were established with such well-known centers as the Institute for Pedagogical Measurements (CITO, the Netherlands) and the Educational Testing Service (ETS, USA). In the framework of cooperation, experts from CITO International (Netherlands) conducted training seminars for the staff of the NTC on the development and preparation of test tasks for an external assessment of academic achievements.

For the successful creation and expansion of the Eurasian space of higher education, many inconsistencies and contradictions still have to be addressed, continue to take into account the best world experience in the field of educational integration, education and science, as well as cooperation with recognized world leaders in higher education. It is logical to expect that the growth of attractiveness of Russian education in the long term will be associated not only with regionalization or the study of the Russian language, but also with the compatibility of Russian education with the most successful world educational systems.

The work on the formation of the Eurasian space of higher education is carried out in several directions. Not only student, but also scientific exchanges are actively developing, giving priority to higher-level specialists and programs with deep interpenetration (long-term scientific internships, joint scientific research, joint publications, the creation of joint research centers, international double degree and double diploma programs). A practical incentive for this may be the convergence of the requirements for the publication of scientific results in the partner countries of the region. There is a need to create coordinated educational standards in the countries of the region, primarily in Russia and China, in Russia and Kazakhstan. This applies to the structure of higher education, the duration of studies, the order of awarding degrees, the issuance of diplomas, the content of educational programs, the mutual recognition of periods and learning outcomes.

The main venues for the implementation of intercultural dialogue in the CIS countries were: Network University of the CIS, Forums of Creative and Scientific Intelligentsia of the CIS Countries, Basic Organization for Languages and Culture of the CIS Member States, Eurasian Association of Universities, regularly held conferences, congresses and other thematic events. Among the significant projects implemented by the Basic Organization for Languages and Culture of the CIS Member States, the following can be distinguished: the innovative educational environment of Lingvapark at Moscow State Linguistic University (MSLU); International Institute of Languages of the CIS Member States; Interuniversity Council on Theological Education of the CIS Member States, transforming into an international network university of theological education of the CIS; International Center for Literary Translation of Literature of the CIS Countries, the practice of which includes annual schools of young translators of fiction of the CIS countries; The Inter-Parliamentary Assembly of the CIS and the educational standards of higher professional education developed by it in the field of translation, linguistics and intercultural communication. Joint study programmes, in addition to teaching goals, harmonize interpersonal communication and contribute to the reduction of interethnic and interfaith conflicts, establishing effective communication among young people. This creates the conditions for the joint formation of future national elites, and, consequently, the deepening of Eurasian integration, contributing to the stability and growth of state economies. 


\section{REFERENCES}

Abdraimov, B. Zh. (2009). Interuniversity cooperation as a key factor in the development of the general educational space: the Eurasian dimension - URL: http:www.ia-centr.ru/expert/4223/.

Abdulkerimov, I.Z., Pavlyuchenko, E.I., Esetova, A.M. (2012). Modern trends in the internationalization of higher education / Problems of the modern economy. - N 3 (43), -- (p.p. 358 - 361)

Altbach, F. J., Raysberg, L., Rumbley, L. (2010). Trends in global higher education: monitoring of the academic revolution Main trends in the development of higher education: global and Bologna changes. - (p.p. 58-94).

Anichkin, E. S. (2015). Strengthening the role of universities in the development of cross-border regions: challenges and solutions. (p.p. 47-52). Economics Profession Business. -

Anikina, E.A., Ivankina, L.I., Sorokina, Yu.S. (2016). The crisis of higher education in Russia: manifestations, causes and consequences Modern problems of science and educationNo. 3.. -. -

Baidenko, V. I. (2004). Competences in vocational education (Toward the development of a competency-based approachNo. 11.) (p.176). Higher education in Russia. -. - -

Barber, M., Donnelly, K. Rizvi, S. (2013). An avalanche is coming: Higher education and the revolution $\operatorname{abead}($ p. 72)

Bidenko, V. I. (2009). Bologna process: learning outcomes and competency-based approach (p. 536). - M.: ICCPPS,---

Bolotov, V. A., Efremova, N. F. (2007). Education Quality Assessment Systems (p. 192). M .: University Book.

Crosier D, Parveva T. (2013) Fundamentals of Educational Planning. The Bologna Process: Its impact in Europe and beyond. UNESCO: International Institute for Educational Planning

Efremova, N.F. (2015).Competences in education: formation and evaluation. (p.416). - M .: National education. .--

Efremova, N.F. (2017). Motivational Aspect of Independent Assessment of Students' Achievements -. - T. 14, No. 2. - (p.p..227-244). Russian Psychological Journal.

Efremova, N.F., Meskhi, B.Ch. (2017). Project "Jean Monnet Chair" as an element of internationalization - No. 1. - Modern problems of science and education.URL: https:www.scienceeducation.ru/en/article/view?id $=26074$

Higher school: problems and prospects: 12th Intern. scientific method. conf., Minsk, October 22-23. 2015, at 2 hours, Part 1. - Minsk: RIVSH, (2015). .-- 246 p.

Kennedy, D. (2007).Writing and Applying Learning Outcomes: A Practical Guide., ,. European Publications on the Writing of Learning Outcomes -, Cork University (Ireland)

Lobanov, N.A. (2015). Lifelong Learning: Continuing Education for Sustainable Development. ; (p.582) Research Institute of Social-Econ. andped. problems continuously. education. St. Petersburg: Leningrad State University named after A.S. Pushkin,

Neumann, Yu. M., Khlebnikov, V. A. (2000). Introduction to the theory of modeling and parameterization of pedagogical tests. (p.168). M. Network of National Qualifications Frameworks CorrespondentsDocuments for Bologna Board, İstanbul, , 2019 URL: http:www.ehea.info/Upload/BFUG_FI_TK_67_5_2_NQF_Correspondents.pdf

Oleinikova, O. N. (2010). Tempus Program in the Russian Federation. What is Tempus? / Alma mater. Bulletin of higher education. - - (p.p. 7-10).

Oleinikova O.N. (2012). Modern approaches to quality management of higher education (p.p. 79-85). Pedagogy and Psychology of Education.. .

Rychen, D. S., Salganik, L. H. (2003). Key Competencies for a Successful Life and a Well-Functioning Society. (p.224). Göttingen: Hogrefe\&Huber Publishers.. 
Smirnova, S. G. (2016). The current state and development tasks of the "Eurasian space of higher education. URL: http:gorchakovfund.ru/news/18524/.

Tereshkovich, P., (2016). Public participation in the modernization of bigher education: the role of civil society in the implementation of the Roadmap for reforming higher education in Belarus: proceedings of an international scientific-practical conference (p.149).Vilnius: Public Bologna Committee,. -

Yerevan Communiqué. Yerevan, (2015). - URL: http:nic.gov.ru/ru/docs/foreign/bolonga/ek.

\section{ABOUT THE AUTHORS}

Nadezhda F. Efremova: nefremova61@dstu.edu.ru

Besarion Ch. Meskhi: reception@donstu.ru

Svetlana V.Shvedova: dstu_oms@mail.ru 